\title{
Analisis Ekonomi Penerapan Pengolahan Beberapa Produk Susu di Kecamatan Selupu Rejang, Kabupaten Rejang Lebong, Bengkulu
}

\section{Economic Analysis of Application of Processing of Some Dairy Products in Selupu Rejang District, Rejang Lebong Regency, Bengkulu}

\section{E. Sulistyowati ${ }^{1}$, S. Mujiharjo ${ }^{2}$, E. Soetrisno ${ }^{1}$, A. Nur Rohmah $^{1}$, Sistanto $^{1}$, dan N. Khotimah ${ }^{1}$}

\author{
${ }^{1}$ Jurusan Peternakan, Fakultas Pertanian, Universitas Bengkulu \\ ${ }^{2}$ Teknologi Pertanian, Fakultas Pertanian, Universitas Bengkulu \\ Email: ensulistyowati@yahoo.com
}

\begin{abstract}
This study aims to analyze the economics of several milk processing products in Selupu Rejang District, Rejang Lebong Regency, Bengkulu. Based on the average score, the color, aroma, taste, preference, smoothness and tenderness of the $0 \%$ and $2 \%$ strawberry caramels were the most preferred. The production cost of dairy cow caramel with the addition of strawberries per pack / 20 mica is Rp. 4,425, the selling price per pack / mica is Rp. 8,000, margin per pack / mica Rp. 3,575, total revenue of Rp. 80,000, profit per kg of milk Rp. 35,750. From the comparison of the economic value of processing products into strawberry caramel flavor has a higher profit with a profit of Rp. 35,750 / 1 of fresh milk when compared with pasteurized milk with a profit of Rp. 11,769 / 1 fresh milk and ginger milk with a profit of Rp. 10,074 / 1 milk.
\end{abstract}

Key words: milk, caramel, strawberry

\section{ABSTRAK}

Penelitian ini bertujuan untuk menganalisis ekonomi beberapa produk pengolahan susu di Kecamatan Selupu Rejang, Kabupaten Rejang Lebong, Bengkulu. Berdasarkan rata-rata skoring penilaian warna, aroma, rasa, kesukaan, kehalusan dan keempukan pada karamel stroberi $0 \%$ dan $2 \%$ adalah yang paling disukai. Biaya produksi karamel susu sapi perah dengan penambahan buah stroberi per bungkus/mika 20 potong adalah Rp. 4.425, harga jual per bungkus/mika Rp. 8.000, margin per bungkus/mika Rp. 3.575, penerimaan total Rp. 80.000, keuntungan per kg susu Rp. 35.750. Dari perbandingan nilai ekonomis pengolahan produk menjadi karamel rasa stroberi memiliki keuntungan yang lebih tinggi dengan keuntungan sebesar Rp. 35.750/l susu segar apabila dibandingkan dengan susu pastuerisasi dengan keuntungan sebesar Rp. 11.769/ 1 susu segar dan susu jahe dengan keuntungan Rp. 10.074/ 1 susu .

Kata kunci: susu, karamel, stroberi

\section{PENDAHULUAN}

Susu merupakan sumber protein dengan mutu yang sangat tinggi. Kadar protein susu segar sekitar 3,5\% dengan kadar lemak sekitar $3,0-3,8 \%$. Susu juga merupakan sumber fosfor yang baik dan sangat kaya kalsium. Protein susu mewakili salah satu mutu protein yang nilainya sepadan dengan daging (Winarno, 2004).

Susu merupakan komoditas yang mudah rusak, mempunyai risiko tinggi, oleh karena itu perlu penanganan dan pengolahan yang hati-hati (Usmiati dan Abubakar, 2009).
Pengolahan susu sangat diperlukan untuk mengatasi permasalahan tersebut, selain dapat meningkatkan daya tahan dari susu tersebut pengolahan susu juga akan meningkatkan nilai jual karena akan terbentuk harga baru dalam proses pengolahannya. Salah satu produk dari usaha pengolahan susu yaitu permen susu (karamel).

Penganekaragaman produk olahan susu sangat penting mengingat masyarakat sangat menggemari berbagai produk diversifikasi yang inovatif dan menyehatkan. Pada saat sekarang dimungkinkan untuk memberi 
flavor yang diinginkan pada karamel, baik flavor alami maupun sintetis. Karamel merupakan produk individual sehingga lebih sulit untuk dilakukan standarisasi produk (Koswara, 2009).

Ada banyak pemberian flavour terhadap karamel agar menarik minat konsumen salah satunya ialah dengan menambahkan flavour stroberi yang disukai oleh konsumen. Penambahan flavour stroberi dapat diberikan secara alami yaitu dengan menambahkan buah stroberi kedalam proses pembuatan karamel atau dengan menambahkan flavour sintetis rasa stroberi.

Buah stroberi mempunyai rasa khas yang manis dan menyegarkan. Selain itu buah stroberi mempunyai kandungan (gizi) yang tinggi dan komposisi gizi cukup lengkap. Buah stroberi dapat dikonsumsi dalam keadaan segar maupun buah yang telah diolah menjadi berbagai macam makanan dan minuman. Aneka macam produk olahan stroberi yaitu selai atau jam, jelly, sirup, es krim, dodol, stroberi pada kue, juice, dan lain sebagainya. Walaupun Stroberi bukan merupakan tanaman asli Indonesia, namun pengembangan komoditas stroberi yang berpola agribisnis dan agrobisnis sebagai salah satu prospek yang baik untuk sumber pendapatan baru dalam sektor pertanian (Rukmana, 1998).

Selain itu stroberi mempunyai kandungan gizi yang tinggi dan komposisi gizi yang cukup lengkap. Kalori sebanyak $37,00 \mathrm{kal}$, protein $0,80 \mathrm{~g}$, lemak $0,50 \mathrm{~g}$, karbohidrat 8,30 g, kalsium 28,00 mg, fosfor $27,00 \mathrm{~g}$, zat besi $0,80 \mathrm{mg}$, vitamin A $60,00 \mathrm{SI}$, vitamin B1 0,03 mg, vitamin C 60,00 mg, air $89,90 \mathrm{~g}$, bagian yang dapat dimakan $96,00 \%$ (Direktorat Gizi Depkes, 1981). Penambahan stroberi pada yogurt susu sapi perah memberikan skor uji organoleptik sebesar 3,8 - 5,0 (Sulistyowati et al, 2016)

Sapi perah dan kebun Stroberi banyak terdapat di wilayah kecamatan Selupu Rejang, Kabupaten Rejang Lebong, Bengkulu. Wilayah ini merupakan lokasi dari $\mathrm{KKN}$ PPM Revolusi Putih Periode 85 UNIB. Produksi susu yang dihasilkan oleh sapi perah di Kecamatan Selupu Rejang ini sangat melimpah dan belum ada pengolahan lebih lanjut, serta stroberi yang tumbuh subur diwilayah ini hanya dimanfaatkan untuk sekedar konsumsi langsung tanpa pengolahan sehingga sangat berpotensi apabila diolah dalam bentuk lain dan menghasilkan nilai ekonomis yang lebih.

Revolusi Putih menggambarkan suatu istilah secara Nasional untuk pemenuhan protein hewani, terutama yang berasal dari susu dan produknya. Sentra peternakan sapi perah ini berada di kecamatan Selupu Rejang (desa Kali Padang, Air Duku, dan Karang Jaya), kabupaten Rejang Lebong, sesuai (900- $1400 \mathrm{~m} \mathrm{dpl}$; $18-26^{\circ} \mathrm{C}$ ) untuk pengembangan sapi perah di luar P. Jawa. Dengan lokasi yang sejuk ini potensi yang ditemui adalah kebun sayuran, pisang Curup, dan buah stroberi.

Dari potensi beberapa hal diatas dengan produksi susu dan stroberi yang melimpah di Kecamatan Selupu Rejang, Kabupaten Rejang Lebong, Bengkulu,untuk dijadikan karamel rasa stroberi. Selain itu juga dibuat susu jahe (Suje) dan Susu Pasteurisasi juga dilakukan selama kegiatan KKN di Kecamatan Selupu Rejang, Kabupaten Rejang Lebong, Bengkulu.

\section{MATERI DAN METODE}

\section{Waktu dan Tempat}

Pelaksanaan dilakukan pada bulan September 2018 di Laboratorium Peternakan, Universitas Bengkulu.

\section{Bahan dan Alat}

Materi yang digunakan dalam penelitian ini adalah susu segar yang diperoleh dari peternakan sapi perah rakyat di Kecamatan Selupu Rejang, Kabupaten Rejang Lebong, Bengkulu. Bahan lainnya yaitu pasta buah stroberi, gula pasir, tepung agar-agar dan mentega. Peralatan yang digunakan untuk membuat permen karamel susu antara lain kuali anti lengket, baskom, pengaduk alumunium, kompor gas, loyang, ayakan 40 mash, mika, blender dan kantong plastik. 
Disain penelitian, variabel yang diamati, dan analisis data

Penelitian ini menggunakan rancangan acak lengkap (RAL) 4 x 4, 4 perlakuan dan 4 ulangan untuk karamel stroberi adalah 0, 2, 4, dan 6\%. Analisis data menggunakan Microsoft Excel.

Variabel yang diamati adalah organoleptik (aroma, rasa, tekstur, kesukaan) menggunakan skoring pada Tabel 1 untuk karamel stroberi. Perhitungan atau analisis ekonomi dilakukan untuk produk karamel stroberi (susu sapi perah). Selain itu, analisis ekonomi juga dilakukan untuk produk susu pasturisasi dan susu jahe (Suje).

\section{Uji organoleptik dan kriteria penilaian}

Penilaian karamel rasa stroberi menggunakan uji organoleptik berdasarkan kriteria berikut. Untuk warna, aroma, rasa, tekstur dan keempukan adalah: 1 = sangat tidak suka, $2=$ tidak suka, $3=$ agak tidak suka, $4=$ netral, $5=$ agak suka, $6=$ suka, $7=$ sangat suka menurut Soekarto (1985) dan Handayani (2007). Kehalusan /tekstur adalah 1 = sangat kasar, $2=$ kasar, $3=$ agak kasar, $4=$ biasa, $5=$ agak lembut/halus, $6=$ lembut/halus, 7 = sangat lembut (Abubakar dan Ilyas, 2005)

\section{Metode pembuatan karamel rasa stroberi}

Pembuatan karamel dengan pasta stroberi (modifikasi Sistanto, 2014):

1. Susu dihomogenkan $\left(\begin{array}{ll}1 & 1\end{array}\right)+$ gula pasir $(200 \mathrm{~g})+$ pasta Stroberi sesuai perlakuan.

2. Adonan dipanaskan sambil diaduk terus menerus sampai terbentuk cairan kental

3. Ditambahkan pasta tepung agar-agar (4 g) dan mentega (8 g) sambil terus diaduk

4. Pemanasan dihentikan setelah mencapai kekentalan yang diinginkan

5. Dimasukkan sedikit adonan ke dalam air dingin dan apabila membentuk bulatan utuh dan mengeras maka karamel sudah matang

6. Dilakukan pencetakan karamel

7. Dilakukan pengemasan karamel
Metode pembuatan susu pasturisasi rasa

1. Susu sebanyak 11 ditambahkan 33\%, dipanaskan pada suhu $65-70^{\circ} \mathrm{C}$ selama 15 menit sambil terus diaduk.

2. Susu diturunkan suhunya sampai $40^{\circ} \mathrm{C}$.

3. Ditambahkan pasta rasa sebanyak 5 ml, diaduk.

4. Susu pasturisasi dikemas dalam gelas berukuran $200 \mathrm{ml} / \mathrm{cup}$.

5. Susu pasturisasi disimpan dalam refrigerator pada suhu $5^{\circ} \mathrm{C}$

\section{Metode pembuatan susu jahe (Suje)}

1. Sari jahe dibuat dari $350 \mathrm{~g}$ jahe segar, dikupas kulitnya, dicuci bersih, diiris, diblender dengan menambahkan $100 \mathrm{ml}$ air, diperas menjadi $350 \mathrm{mg}$ sari jahe.

2. Susu 11 ditambah sari jahe $350 \mathrm{mg}$, dimasak dan diaduk terus hingga menggumpal dan kering.

3. Susu jahe ini kemudian digiling dan diayak hingga halus.

4. Susu jahe dikemas dalam kantong $100 \mathrm{~g} /$ bungkus.

\section{HASIL DAN PEMBAHASAN}

\section{Hasil uji organoleptik terhadap karamel rasa stroberi}

Tingkat kesukaan berdasarkan uji organoleptik, karamel susu sapi perah dengan penambahan buah stroberi disajikan pada tabel berikut .

Tabel 1. Rataan Tingkat kesukaan berdasarkan uji organoleptik, karamel susu sapi perah dengan penambahan buah stroberi

\begin{tabular}{lllll}
\hline Variabel & $\begin{array}{c}\text { Stroberi } \\
(0 \%)\end{array}$ & $\begin{array}{c}\text { Stroberi } \\
(2 \%)\end{array}$ & $\begin{array}{c}\text { Stroberi } \\
(4 \%)\end{array}$ & $\begin{array}{c}\text { Stroberi } \\
(6 \%)\end{array}$ \\
\hline Warna & 5,29 & 5,23 & 4,57 & 4,75 \\
Aroma & 5,5 & 5,41 & 4,73 & 4,94 \\
Rasa & 5,66 & 5,25 & 4,88 & 4,91 \\
Kesukaan & 5,53 & 5,33 & 4,67 & 4,81 \\
Kehalusan & 4,45 & 4,61 & 4,68 & 4,52 \\
Keempukan & 4,98 & 4,83 & 4,59 & 4,63 \\
\hline
\end{tabular}

Tabel 1. Menunjukkan bahwa secara keseluruhan skor penilaian rata-rata terhadap warna, aroma, rasa, kesukaan, kehalusan dan keempukan karamel berkisar antara 4,45 terendah (pada kehalusan/tekstur karamel 
dengan stroberi 0\%) dan 5,66 tertinggi (pada rasa karamel dengan penambahan pasta buah stroberi 0\%). Ini berarti tingkat kesukaan panelis terhadap karamel berkisar antara netral dan suka. Berdasarkan skoring warna, aroma, rasa, kesukaan, kehalusan dan keempukan pada stroberi $0 \%$ dan $2 \%$ menunjukan skoring yang tidak terlalu jauh berbeda dan paling disukai.

\section{Analisis ekonomis pembuatan karamel stroberi}

Analisis ekonomis pembuatan karamel susu sapi ditambahkan pasta stroberi disajikan pada tabel berikut. Hasil analisis ekonomis pembuatan susu karamel menunjukkan bahwa biaya produksi per 1 susu adalah Rp. 44.250, menghasilkan 10 pack @ 20 potong kecil, dengan harga produk Rp. 8.000/pack, margin dari penjualan adalah Rp. 35. 750/1 susu.

Tabel 2. Analisis ekonomis pembuatan karamel susu sapi ditambahkan pasta buah stroberi

\begin{tabular}{|c|c|c|}
\hline No & Uraian & Jumlah (Rp) \\
\hline 1. & Susu Sapi 11 x Rp. 8.000 & 8.000 \\
\hline 2. & $\begin{array}{l}\text { Gula } 400 / 1000 \mathrm{~g} \mathrm{x} \mathrm{Rp.} \\
12.000\end{array}$ & 4,800 \\
\hline 3. & Agar 4/6 g x Rp. 3.000 & 2.000 \\
\hline 4. & $\begin{array}{l}\text { Margarin 8/200 g x Rp. } \\
5.000\end{array}$ & 200 \\
\hline 5. & $\begin{array}{l}\text { Mika 10/10 buah x Rp. } \\
2.000\end{array}$ & 2.000 \\
\hline 6. & Gas $2 / 8$ jam x Rp. 25.000 & 6.250 \\
\hline 7. & $\begin{array}{l}\text { Pasta Stroberi } 60 / 250 \mathrm{~g} \mathrm{x} \\
\text { Rp. } 25.000\end{array}$ & 6.000 \\
\hline 8. & $\begin{array}{l}\text { Tenaga Kerja } 3 / 8 \text { jam } x \\
\text { Rp. } 40.000\end{array}$ & 15.000 \\
\hline \multicolumn{2}{|c|}{ Total } & 44.250 \\
\hline \multicolumn{2}{|c|}{$\begin{array}{l}\text { Biaya Produksi per } \\
\text { bungkus/mika ( } 20 \text { potong/mika) }\end{array}$} & 4.425 \\
\hline \multicolumn{2}{|c|}{ Harga jual Per bungkus/mika } & 8.000 \\
\hline \multicolumn{2}{|c|}{ Margin per bungkus/mika } & 3.575 \\
\hline \multicolumn{2}{|c|}{ Penerimaan total } & 80.000 \\
\hline \multicolumn{2}{|c|}{ Keuntungan per 1 susu } & 35.750 \\
\hline
\end{tabular}

\section{Analisis ekonomis pembuatan susu pasturisasi rasa}

Hasil analisis ekonomis pembuatan susu pasturisasi menunjukkan bahwa biaya produksi per 1 susu adalah Rp. 13.231, menghasilkan 5 gelas @ $200 \mathrm{ml}$, dengan harga produk Rp. 5.000/pack, margin dari penjualan adalah Rp. 11.769/1 susu.

Tabel 3. Analisis ekonomis pembuatan susu sapi perah yang dipasteurisasi

\begin{tabular}{|c|c|c|}
\hline $\mathrm{No}$ & Uraian & $\begin{array}{l}\text { Jumlah } \\
\text { (Rp) }\end{array}$ \\
\hline 1 & Susu 11 x Rp. 8.000 & 8.000 \\
\hline 2 & $\begin{array}{l}\text { Gula } 100 / 1000 \mathrm{~g} \times \mathrm{Rp} . \\
12.000\end{array}$ & 1.200 \\
\hline 3 & Pasta $1 / 10$ botol x Rp. 5.000 & 500 \\
\hline 4 & Cup gelas 5 x Rp.100 & 1500 \\
\hline 5 & $\begin{array}{l}\text { Gas } 15 / 480 \text { menit x Rp. } \\
25.000\end{array}$ & 781,25 \\
\hline 6 & $\begin{array}{l}\text { Tenaga Kerja } 15 / 480 \text { menit } x \\
\text { Rp. } 40.000\end{array}$ & 1.250 \\
\hline & Total & 13.231 \\
\hline \multicolumn{2}{|c|}{ BiayaProduksi per gelas } & 2.646 \\
\hline \multicolumn{2}{|c|}{ Harga jual per $\xi$} & 5000 \\
\hline \multicolumn{2}{|c|}{ Margin per gelas } & 2.354 \\
\hline \multicolumn{2}{|c|}{ Penerimaan total } & 25.000 \\
\hline \multicolumn{2}{|c|}{ Keuntungan per 1 susu } & 11.769 \\
\hline
\end{tabular}

\section{Analisis ekonomis pembuatan susu jahe (Suje)}

Hasil analisis ekonomis pembuatan susu jahe (Suje) menunjukkan bahwa biaya produksi per 1 susu adalah Rp. 39.926, menghasilkan 5 pack Suje @ 100 g, dengan harga produk Rp. 10.000/pack, margin dari penjualan adalah Rp. 10.074/1 susu.

Tabel 4. Analisis ekonomis pembuatan susu jahe (Suje)

\begin{tabular}{llr}
\hline No & Uraian & Jumlah (Rp) \\
\hline 1 & Susu 11 x Rp. 8.000 & 8.000 \\
2 & Gula 333/1000 g x Rp. & 3.996 \\
& 12.000 & \\
3 & Jahe 333/1000 g x Rp. & 8.325 \\
& 25.000 & 5.000 \\
4 & Air 1000 g x Rp. 5.000 & 750 \\
5 & Plastik kemasan 5 buah x & \\
& Rp. 150 & 4.688 \\
6 & Gas 90/480 menit x Rp. & 9.167 \\
& 25.000 & \\
7 & Tenaga Kerja110/480 menit & 39.926 \\
\hline & x Rp. 40.000 & 7.986 \\
& Total & 10.000 \\
& Biaya produksi per 100 g & 2.015 \\
& Harga jual per bungkus & 50.000 \\
& Margin per bungkus & 10.074 \\
\hline & Penerimaan total \\
Keuntungan per 1 susu &
\end{tabular}


Dari Tabel 2, 3 dan 4 diketahui bahwa margin karamel susu sapi rasa stroberi memberikan margin yang lebih tinggi apabila dibandingkan dengan margin susu sapi yang dipasteurisasi dan margin susu jahe (Suje).

\section{KESIMPULAN}

Berdasarkan hasil kegiatan dapat disimpulkan bahwa :

1. Hasil uji organoleptik terhadap produk karamel rasa sroberi adalah secara skoring penilaian rata-rata terhadap warna, aroma, rasa, kesukaan, kehalusan dan keempukan karamel berkisar antara 4,45 - 5,66. Ini berarti tingkat kesukaan panelis terhadap karamel berkisar antara netral dan suka. Berdasarkan rata-rata skoring warna, aroma, rasa, kesukaan, kehalusan dan keempukan pada karamel stroberi 0\% dan $2 \%$ adalah yang paling disukai.

2. Biaya produksi karamel susu sapi perah dengan penambahan buah stroberi per bungkus/mika 20 potong adalah Rp. 4.425, harga jual per bungkus/mika Rp. 8.000, margin per bungkus/mika Rp. 3.575, penerimaan total Rp. 80.000, keuntungan Rp. 35.750/l susu.

3. Biaya produksi susu sapi perah yang dipasteurisasi Rp. 13.231/cup, harga jual Rp. 5.000/cup, margin Rp. 2.354/cup, penerimaan total Rp. 25.000, dan keuntungan Rp. 11.769/1 susu.

4. Biaya produksi Susu Jahe (Suje) Rp. 7.986/pack, harga jual Rp. 10.000/pack, margin Rp.2.015/pack, penerimaan total Rp. 50.000, keuntungan Rp. 10.074/1 susu.

5. Dari perbandingan nilai ekonomis pengolahan beberapa produk susu sapi perah, tertinggi berturut- turut adalah karamel susu -stroberi, susu pasteurisasi dan susu jahe (Suje).

\section{UCAPAN TERIMA KASIH}

Penelitian ini merupakan bagian dari kegiatan yang dilaksakan atas biaya hibah program Direktorat Riset dan Pengabdian Masyarakat, Direktorat Jenderal Penguatan
Riset dan Pengembangan, Kementerian Riset, Teknologi, dan Pendidikan Tinggi. Sesuai dengan Perjanjian Pendanaan Pelaksanaan Program Pengabdian Masyarakat Nomor : 023/SP2H/PPM/DRPM/1/2018.

\section{DAFTAR PUSTAKA}

Abubakar dan M. Ilyas. 2005. Mutu susu karamel asal susu pecah selama penyimpanan. Seminar Nasional Teknologi Peternakan dan Veteriner 2005.

Direktorat Gizi Depkes. RI. 1981. Daftar Komposisi Bahan Makanan. Jakarta: Bhratara Karya Aksara.

Handayani, E. 2007. Pembuatan karamel dari susu sapi (kemasan) dan karakterisasi fisik serta pHnya. Skripsi. Departemen Fisika. Fakultas Matematika dan Ilmu Pengetahuan Alam. Institut Pertanian Bogor. Bogor.

Koswara, S. 2009. Teknologi Pembuatan Permen. Ebookpangan.com. Diakses pada tanggal 21 Mei 2018.

Rukmana, H. R., 1998. Stroberi Budidaya dan Pascapanen. Kanisius. Yogyakarta

Sistanto, E. Soetrisno, dan R. Saepudin. 2014. Sifat Fisikokimia dan Organoleptik Permen Susu (Karamel) Rasa Jahe (Zingiber officinale Roscoe) dan Temulawak (Curcuma xanthorriza Roxb). Jurusan Peternakan, Fakultas Pertanian, Universitas Bengkulu. Jurnal Sains Peternakan Indonesia. 9 (2) : 81-90.

Soekarto S. T. 1985. Penilaian Organoleptik untuk Industri Pangan dan Hasil Pertanian. Bharata Karya Aksara. Jakarta.

Sulistyowati, E., B. S. Priyono, E. Haryanti, dan Sistanto. 2016. Tingkat Kesukaan dan Analisis Ekonomi Produk Olahan. 
Susu Spesifik Lokasi. Jurnal Sain Peternakan Indonesia. 11(2): 118-125

Usmiati, S dan Abubakar. 2009. Teknologi Pengolahan Susu. Balai Besar
Penelitian dan Pengembangan

Pascapanen Pertanian. Bogor. 59 Hlm.

Winarno, F. G. 2004. Kimia pangan dan Gizi. Jakarta : Gramedia Pustaka Utama. 